\title{
Effects of garlic supplementation on in vitro nutrient digestibility, rumen fermentation, and gas production
}

\author{
M.R. Kekana ${ }^{1 \#}$, D. Luseba ${ }^{2}$ \& M.C. Muyu ${ }^{3}$ \\ ${ }^{1}$ Institute for Animal Production, Department of Agriculture: Western Cape, PO Box 351, Oudtshoorn 6620, South Africa \\ ${ }^{2}$ Department of Animal Sciences, Faculty of Science, Tshwane University of Technology, Private Bag X680, Pretoria \\ 0001, South Africa. \\ ${ }^{3}$ Animal Production Institute, Ruminant Nutrition, Agriculture Research Council, Pretoria, Private Bag X2, Irene 0062,
} South Africa

(Submitted 9 April 2020; Accepted 21 February 2021; Published 27 April 2021)

\author{
Copyright resides with the authors in terms of the Creative Commons Attribution 4.0 South African Licence. \\ See: http://creativecommons.org/licenses/by/4.0/za \\ Condition of use: The user may copy, distribute, transmit and adapt the work, but must recognize the authors and the South African \\ Journal of Animal Science.
}

\begin{abstract}
Garlic contains secondary metabolites with antimicrobial properties that can alter nutrient digestibility and rumen fermentation, similar to other antimicrobial products. The objectives of the study were to evaluate the effects of garlic powder and garlic juice on in vitro nutrient digestibility, rumen fermentation, and gas production. The treatments consisted of control with no additives, garlic powder, and garlic juice at $0.5 \mathrm{ml}$ and $1 \mathrm{ml}$. The digestibility of dry matter, crude protein and neutral detergent fibre were determined after 48 hours incubation. Rumen ammonia nitrogen and volatile fatty acids were determined at 12 hours and 24 hours incubation. The cumulative gas production was recorded periodically over 48 hours. The in vitro dry matter disappearance decreased with $1 \mathrm{ml}$ of garlic juice compared with control. The crude protein degradability in garlic powder and garlic juice was lower than in control. Volatile fatty acids increased in all treatments. Individual volatile fatty acids were significantly different, especially propionate, whereas the acetate to propionate ratio was reduced by garlic juice, and ammonia nitrogen was reduced by garlic powder and $0.5 \mathrm{ml}$ of garlic juice. The cumulative gas production increased significantly with both levels of garlic juice. The addition of garlic juice at $0.5 \mathrm{~mL} / 100 \mathrm{ml}$ could enhance the production of propionate, and reduce the acetate to propionate ratio, implying that the supply of hydrogen for methanogens was limited.
\end{abstract}

Keywords: garlic juice, garlic powder, ruminants, volatile fatty acids

"Corresponding author: molatelom@elsenburg.com

\section{Introduction}

In livestock production systems, pharmaceutical technologies such as antimicrobials are commonly used to increase the average daily gain and improve feed efficiency. They also prevent disease and metabolic disorders (McGuffey et al., 2001). Antimicrobial ionophores have been used extensively to manipulate the rumen microbial population, increase propionate, reduce dietary protein deamination, and decrease methane production (Broderick, 2004; Odongo et al., 2007). Despite the positive nutritional and health effects of antimicrobials, there is increasing public and scientific concern about their use in animal feed, fuelled by the presence of resistant bacteria in both animals and humans (Marshall \& Levy, 2011), residues in milk and carcasses (Benchaar et al., 2008) and the release of contaminating residues into the environment (Yang \& Carlson, 2004), all of which pose a serious risk to public health. As a result, certain countries have banned their use in animal feed (Benchaar et al., 2008).

Considerable efforts have been made to develop alternatives that would improve feed efficiency and mitigate gas emission. In recent years, there has been growing interest in plants and their extracts (Windisch et al., 2009). Garlic has been used as a spice and native medicine throughout human history (Revlin, 2001). It contains many secondary metabolites with antimicrobial properties (Kasuga et al., 2001; Amagase, 2006) and may be useful in improving rumen fermentation. Garlic powder contains alliin and oil-soluble sulphur compounds, but not allicin (Amagase et al., 2001), whereas garlic juice has allicin and not alliin (Kasuga et al., 2001). The presence of antimicrobial alliin and allicin in garlic enables it to decrease acetate, increase propionate production, and improve the efficiency of nutrient use by decreasing methane production and 
ammonia in vitro (Cardozo et al., 2005; Busquet et al., 2006; Kamel et al., 2008). However, the effects of garlic and its derivatives on rumen, the microbial population and ruminal fermentation are not consistent (Cardozo et al., 2005; Kongmun et al., 2010). There are discrepancies in studies that have been attributed to the differences in types and doses of antimicrobial compounds in garlic. For example, garlic powder and garlic oil had no effect on dry matter digestibility either in vitro or in vivo (Busquet et al., 2005a, 2005b; Wanapat et al., 2008; Kongmun et al., 2010). Ahmed et al. (2009) reported that inclusion of garlic juice at $2.5 \%$ improved the digestibility of dry matter, but dry matter digestibility was reduced at a dose of $7.5 \%$. Therefore, the present study was conducted to evaluate the effects of garlic powder and garlic juice on in vitro gas production, digestibility and fermentation products of a basal concentrate dairy diet.

\section{Materials and methods}

Garlic cloves were washed, peeled and blended for one minute with a Waring Blender®. The extract was transferred into a strainer and floating debris was removed. Garlic juice was filtered through a nylon cloth to separate the remaining pulp from the pure juice. Fresh rumen fluid was provided by the Agricultural Research Council-Dairy section. Two early lactating Holstein cows were used as donors of rumen fluid for the in vitro experiments. The animals were fed an early lactating diet as total mixed ration (TMR) provided twice daily (09h00 and 14h00) ad libitum (Table 1). The animals were restrained in a crush pen prior to collection. The protocol for care and collection of the rumen fluid was accepted by the ARC-Animal Ethics Committee. The diet was formulated to meet the nutrient requirements of the cows (NRC, 2001). Rumen fluid was collected from each Holstein dairy cow through a cannula. The flask was pre-warmed by filling it with hot water to limit temperature loss. It was emptied prior to collection. Both the liquid and the solid contents were removed by hand from the cannula. The solid contents ensured the inclusion of fibrolytic bacterial species. Pooled rumen content was squeezed through four layers of cheesecloth into the thermos flask and the solid rumen contents were then mixed with the rumen fluid in the flask. The flask was filled completely to eliminate oxygen (Mauricio et al., 1999). After collection, the flask was transported immediately to the laboratory. The strained rumen fluid was continuously purged under oxygen-free carbon dioxide $\left(\mathrm{CO}_{2}\right)$ gas and kept at 39 ${ }^{\circ} \mathrm{C}$. The $\mathrm{pH}$ was measured and a buffer solution was prepared according to Goering and Van Soest (1970). The magnetic stir bar was placed in the jar to make the solution homogeneous. The treatments consisted of control with no additives (C), garlic powder (GP) (53 mg) and garlic juice (GJ) at two levels, namely GJ1 at $0.5 \mathrm{ml}$ and GJ2 at $1 \mathrm{ml}$.

Table 1 Diet and chemical composition of total mixed ration supplemented with garlic

\begin{tabular}{lclr}
\hline Ingredients & \% Dry matter & Chemical composition & \% Dry matter \\
\hline Eragrostis grass & 13.08 & Fat & 3.30 \\
Molasses cane & 12.34 & Crude protein & 15.91 \\
Hominy chop & 3.74 & Calcium & 0.66 \\
Wheat bran & 7.37 & Phosphorus & 0.43 \\
Urea & 0.41 & Potassium & 1.50 \\
Maize grain coarse & 32.89 & Magnesium & 0.31 \\
Mineral and vitamin mix & 0.41 & ME, MJ/Kg DM & 2.53 \\
Salt & 0.20 & & \\
Lucerne & 18.69 & & \\
Cotton seed meal & 10.70 & & \\
& & & \\
\hline
\end{tabular}

ME: metabolizable energy

Nylon bags (ANKOM Technology R510), with a pore size of $50 \mu \mathrm{m}$, were used in the trial with an ANKOM Daisy" incubator (ANKOM Technologies Corp., Fairport, NY). The bags were filled with samples of $0.5 \mathrm{~g}$ of the diet (Table 1) and sealed with an impulse sealer. The bags were incubated in triplicate for $0,2,4$, and 8 hours. Since incubation times that were longer than 12 hours were not expected to leave sufficient residue for chemical analysis, quintuplicate bags were prepared for 12, 24, 36, and 48 hours' incubation. At the end of the incubation, the bags were removed from the incubator and the solution was discarded. The bags, including the zero samples, were washed immediately with cold tap water until the water became 
clear. All the bags were then dried in a forced air drying oven at $60^{\circ} \mathrm{C}$ for 48 hours. From the quintuplicate bags, triplicate bags were combined for analyses of CP using the Micro-Kjeldahl method (AOAC, 2000) and duplicate bags were kept for analyses of neutral detergent fibre (NDF) (Van Soest \& Robertson, 1985). Ruminal in vitro disappearance of DM was calculated as the difference between the amounts in the original sample and in the residue. The DM and CP disappearance data were used to estimate ruminal kinetic parameters using the exponential model:

$$
P=a+b\left[1-e^{c t}\right]
$$

where: $\mathrm{P}=$ potential degradability at time $\mathrm{t}$,

$\mathrm{a}=$ rapidly degradable fraction,

$\mathrm{b}=$ slowly degradable fraction,

$\mathrm{c}=$ constant rate at which the fraction described by $\mathrm{b}$ is degraded per hour $(\mathrm{h})$, and

$\mathrm{t}=$ time of incubation.

Ruminal effective degradability (ED) of DM and $\mathrm{CP}$ at a rumen flow rate $(\mathrm{k})$ with three in rumen flow rate of 0.02 hours, 0.05 hours and 0.08 hours was estimated using the equation:

$$
E D=\frac{a+b x c}{c+k}
$$

where: $a, b$ and c are as described above (Theodorou et al., 1994).

Incubations were conducted in $250 \mathrm{ml}$ glass bottles. The bottles were rinsed with distilled water and flushed with $\mathrm{CO}_{2}$ before $0.5 \mathrm{~g}$ of substrate and $100 \mathrm{ml}$ of buffered fluid were added. Triplicate bottles were incubated for each treatment and each incubation time (12 and 24 hours). The temperature of the bottles was raised to $39^{\circ} \mathrm{C}$ prior to incubation by putting them in the water bath. After incubation, bottles were placed in cold water and $4 \mathrm{ml}$ were sampled for analysis of volatile fatty acids (VFAs) and ammonia nitrogen $\left(\mathrm{NH}_{3}-\mathrm{N}\right)$. The samples were stored at $-20^{\circ} \mathrm{C}$ until analysed. Procedures used for gas production were based on the reading pressure technique (Theodorou et al., 1994; Mauricio et al., 1999) with automated gas pressure devices from the ANKOM system. The bottles were fitted with ANKOM $^{\mathrm{RF}}$ gas production system modules (ANKOM ${ }^{\circledR}$ Technologies corp., Fairport, NY) and placed in an incubator for 48 hours and the temperature was maintained at $39^{\circ} \mathrm{C}$. Incubations were conducted in $250 \mathrm{~mL}$ glass bottles similar to the ones used in fermentation. The initial gas was recorded and then every 4 hours. These were converted to millilitres of gas produced as stated by the ANKOM system. Samples of the TMR were dried at $60{ }^{\circ} \mathrm{C}$ for 48 hours and then ground through a $1 \mathrm{~mm}$ screen. The dry matter of feed was determined according to Goering and Van Soest (1970). Crude protein was determined with the Kjeldahl method. Neutral detergent fibre of all samples was determined with the procedure of Van Soest and Robertson (1985).

All parameters were analysed with ANOVA using the general linear model procedure of SAS (SAS Institute Inc., Cary, North Carolina, USA). The a, b, c, and ED parameters were estimated with nonlinear regression procedure (NLIN). The average NDF disappearance of GP, GJ1, and GJ2 were each compared against the control. The GJ2 treatment was compared with GJ1 by a 2-tailed t-test for independent means.

\section{Results and Discussion}

Effects of garlic powder and garlic juice resulted in variations $(P<0.05)$ in DM and CP degradation, suggesting that these products differ in their active components, as demonstrated by their digestion patterns (Table 2). Percentage NDF disappearance $(C=53.0, \mathrm{GP}=56.5$, GJ1 $=54.8, \mathrm{GJ} 2=52.7, \mathrm{SE}=3.29)$ did not differ $(P>0.05)$ among treatments, suggesting that neither garlic powder nor garlic juice had any effect on fibre digestion. The GJ1 treatment reduced $(P<0.05) \mathrm{CP}$ degradation more than GP and GJ2.

The change of CP disappearance over time is illustrated in Figure 1. The relationship between DM and CP disappearance is shown in Figure 2. The means in DM and CP were 0.2587 and 0.7966 , respectively, and showed a strong positive relationship $\left(\mathrm{R}^{2}=0.81 ; P<0.001\right)$. Treatment GJ1 resulted in lower ammonia $\mathrm{N}(P<0.05)$ and higher cumulative gas production $(P<0.05)$ compared with $\mathrm{C}$, GP and GJ2 (Table 3). Garlic treatments increased the total VFAs compared with $C(P<0.05)$ and did not affect the molar proportion of acetate $(P>0.05)$. The juice treatments resulted in higher molar proportion of propionate $(P$ $<0.05)$. Butyrate proportion was lower in GP $(P<0.05)$ and higher in $C$ and GJ1 $(P<0.05)$. The molar proportion of iso-valerate and iso-butyrate was lower $(P<0.05)$ in GP compared with $\mathrm{C}$. 
Table 2 Effect of garlic powder and garlic juice on dry matter, crude protein digestibility and neutral detergent fibre in vitro

\begin{tabular}{|c|c|c|c|c|c|c|}
\hline \multirow[b]{2}{*}{ Nutrient } & \multirow{2}{*}{$\begin{array}{l}\text { Estimated } \\
\text { parameter }\end{array}$} & \multicolumn{4}{|c|}{ Treatments } & \multirow{2}{*}{ SE } \\
\hline & & C & GP & GJ1 & GJ2 & \\
\hline \multirow[t]{6}{*}{ Dry matter } & A & 50.3 & 47.9 & 46.7 & 44.8 & 5.21 \\
\hline & B & $30.6^{b}$ & $32.2^{\mathrm{b}}$ & $37.2^{\mathrm{ab}}$ & $41.2^{\mathrm{a}}$ & 3.83 \\
\hline & $\mathrm{C}$ & 0.074 & 0.100 & 0.072 & 0.068 & 0.04 \\
\hline & ED2 & $74.4^{\mathrm{a}}$ & $74.7^{\mathrm{a}}$ & $73.2^{\mathrm{ab}}$ & $70.6^{\mathrm{b}}$ & 1.02 \\
\hline & ED5 & $68.7^{\mathrm{ab}}$ & $69.3^{\mathrm{a}}$ & $66.7^{\mathrm{bc}}$ & $64.8^{c}$ & 2.23 \\
\hline & ED8 & $65.3^{\mathrm{ab}}$ & $65.7^{\mathrm{a}}$ & $62.5^{\mathrm{bc}}$ & $61.2^{c}$ & 1.93 \\
\hline \multirow[t]{6}{*}{ Crude protein } & A & $39.2^{\mathrm{a}}$ & $33.2^{c}$ & $32.3^{d}$ & $38.4^{\mathrm{b}}$ & 0.64 \\
\hline & B & $32.4^{\mathrm{a}}$ & $26.7^{\mathrm{b}}$ & $27.4^{\mathrm{b}}$ & $26.0^{\mathrm{b}}$ & 0.54 \\
\hline & $C$ & $0.090^{\mathrm{b}}$ & $0.086^{\mathrm{b}}$ & $0.063^{c}$ & $0.153^{\mathrm{a}}$ & 0.01 \\
\hline & ED2 & $65.7^{\mathrm{a}}$ & $54.8^{\mathrm{c}}$ & $53.1^{d}$ & $61.3^{\mathrm{b}}$ & 1.09 \\
\hline & ED5 & $60.0^{\mathrm{a}}$ & $50.1^{c}$ & $47.6^{d}$ & $57.9^{\mathrm{b}}$ & 1.12 \\
\hline & ED8 & $56.3^{\mathrm{a}}$ & $47.1^{\mathrm{C}}$ & $44.3^{d}$ & $55.4^{b}$ & 1.12 \\
\hline
\end{tabular}

A: rapidly degradable fraction, $B$ : slowly degradable fraction, C: constant rate at which $b$ is degraded per $h$, ED2, ED5, and ED8: effective degradability rates at $0.02 \mathrm{~h}, 0.05 \mathrm{~h}$, and $0.08 \mathrm{~h}$, respectively.

C: control; GP: garlic powder; GJ1, $0.5 \mathrm{ml}$ garlic juice, GJ2: $1.0 \mathrm{ml}$ garlic juice,

a,b,c,d Within rows means with a common superscript did not differ with probability $P=0.05$

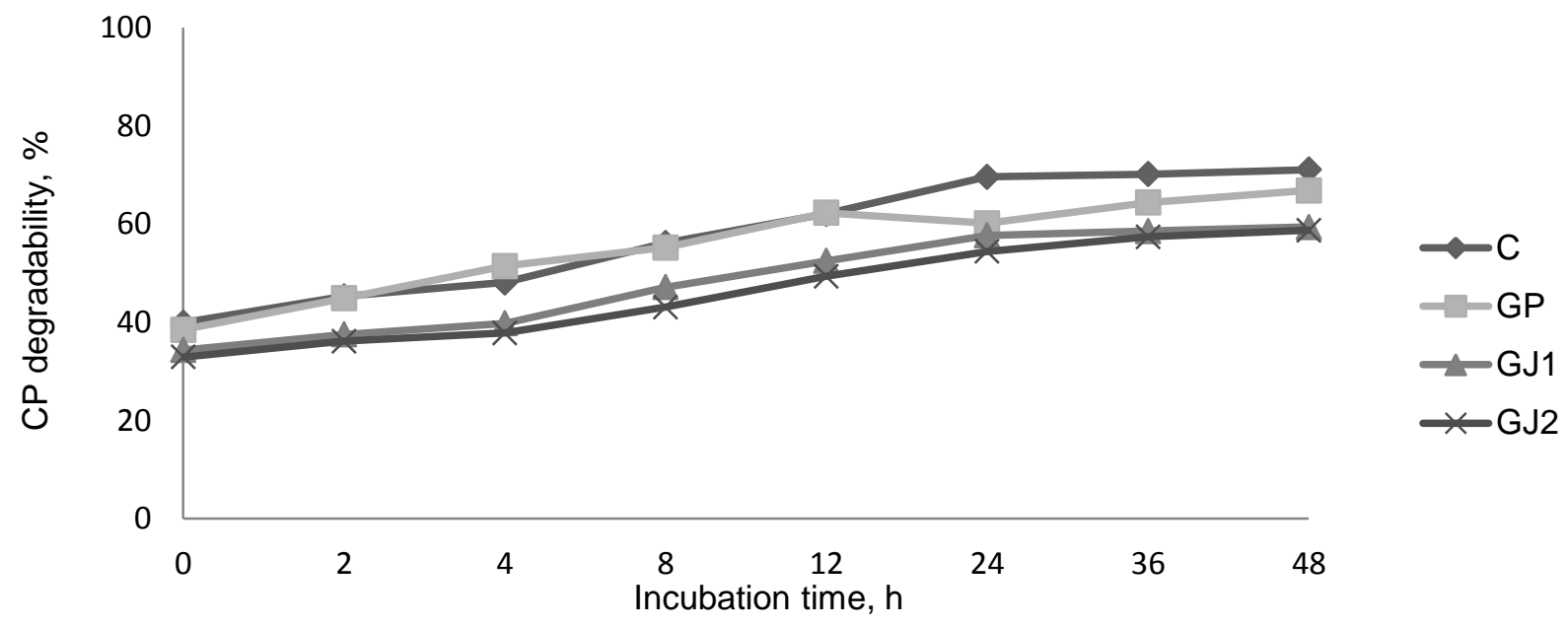

Figure 1 Change of crude protein disappearance as affected by garlic supplementation

C: control; GP: garlic powder; GJ1: garlic juice at low dose; GJ2: garlic juice at high dose 


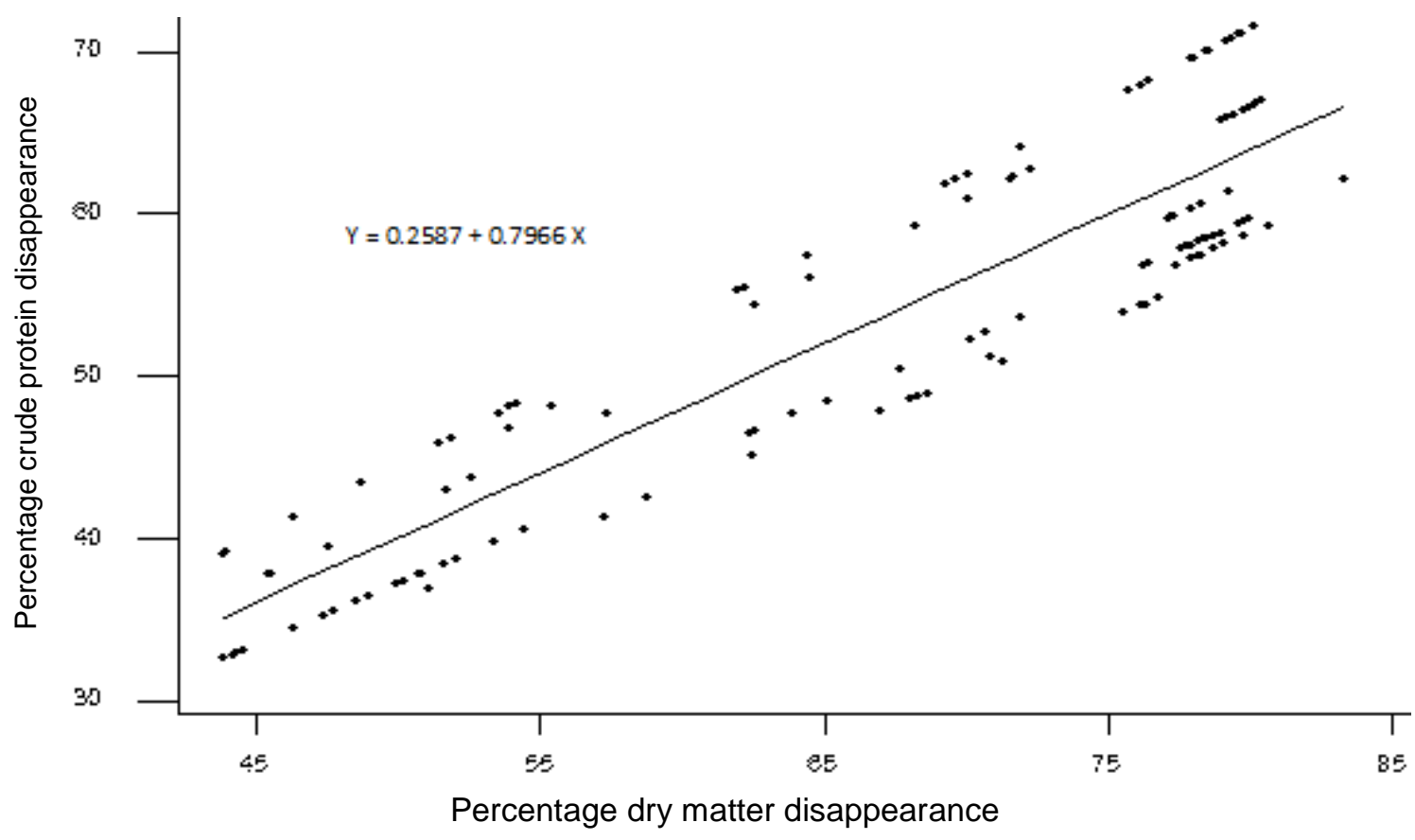

Figure 2 Relationship between dry matter and crude protein disappearance

Table 3 Rumen parameters as affected by in vitro supplementation of garlic powder and garlic juice

\begin{tabular}{|c|c|c|c|c|c|}
\hline \multirow{2}{*}{ Parameters } & \multicolumn{4}{|c|}{ Treatments } & \multirow{2}{*}{ SE } \\
\hline & C & GP & GJ1 & GJ2 & \\
\hline $\mathrm{NH}_{3}-\mathrm{N}$ & $6.9^{\mathrm{a}}$ & $6.7^{\mathrm{b}}$ & $6.3^{\mathrm{c}}$ & $6.8^{\mathrm{ab}}$ & 1.25 \\
\hline Gas, $\mathrm{mL}$ & $42.8^{\mathrm{c}}$ & $34.5^{\mathrm{d}}$ & $94.9^{\mathrm{a}}$ & $71.9^{\mathrm{b}}$ & 0.60 \\
\hline Total VFA, mmol/L & $128.3^{c}$ & $133.8^{\mathrm{b}}$ & $135.5^{\mathrm{a}}$ & $136.5^{\mathrm{a}}$ & 0.74 \\
\hline \multicolumn{6}{|l|}{ Volatile fatty acids, $\%$} \\
\hline Acetate & 62.7 & 62.4 & 62.2 & 62.5 & 0.08 \\
\hline Propionate & $16.5^{\mathrm{b}}$ & $16.9^{b}$ & $18.2^{\mathrm{a}}$ & $18.2^{\mathrm{a}}$ & 0.30 \\
\hline Butyrate & $14.3^{\mathrm{a}}$ & $13.1^{b}$ & $14.5^{\mathrm{a}}$ & $13.5^{\mathrm{ab}}$ & 0.17 \\
\hline Valerate & $1.5^{\mathrm{ab}}$ & $1.4^{\mathrm{b}}$ & $1.6^{\mathrm{a}}$ & $1.5^{\mathrm{ab}}$ & 0.01 \\
\hline Iso-valerate & $2.8^{\mathrm{a}}$ & $2.5^{\mathrm{b}}$ & $2.8^{\mathrm{a}}$ & $2.7^{\mathrm{ab}}$ & 0.04 \\
\hline Iso-butyrate & $1.7^{\mathrm{a}}$ & $1.6^{\mathrm{b}}$ & $1.7^{\mathrm{a}}$ & $1.6^{\mathrm{ab}}$ & 0.02 \\
\hline Acetate to propionate ratio & $3.8^{\mathrm{a}}$ & $3.6^{\mathrm{a}}$ & $3.4^{\mathrm{b}}$ & $3.4^{b}$ & 0.03 \\
\hline
\end{tabular}

C: control, GP: garlic powder, GJ: $0.5 \mathrm{ml}$ garlic juice, GJ2: 1,0 ml garlic juice

VFA: volatile fatty acids; $\mathrm{NH}_{3}-\mathrm{N}$ : ammonia nitrogen

a,b,c,d Within rows means with a common superscript did not differ with probability $P=0.05$

The cumulative gas production did not differ at the first four hours. Increased gas production was observed during the first 8 hours of incubation for all the treatment groups (Figure 3). From 12 hours through to the end of the incubation period, cumulative gas production was higher in GJ1 and lower in GP than in the rest of the treatments. 


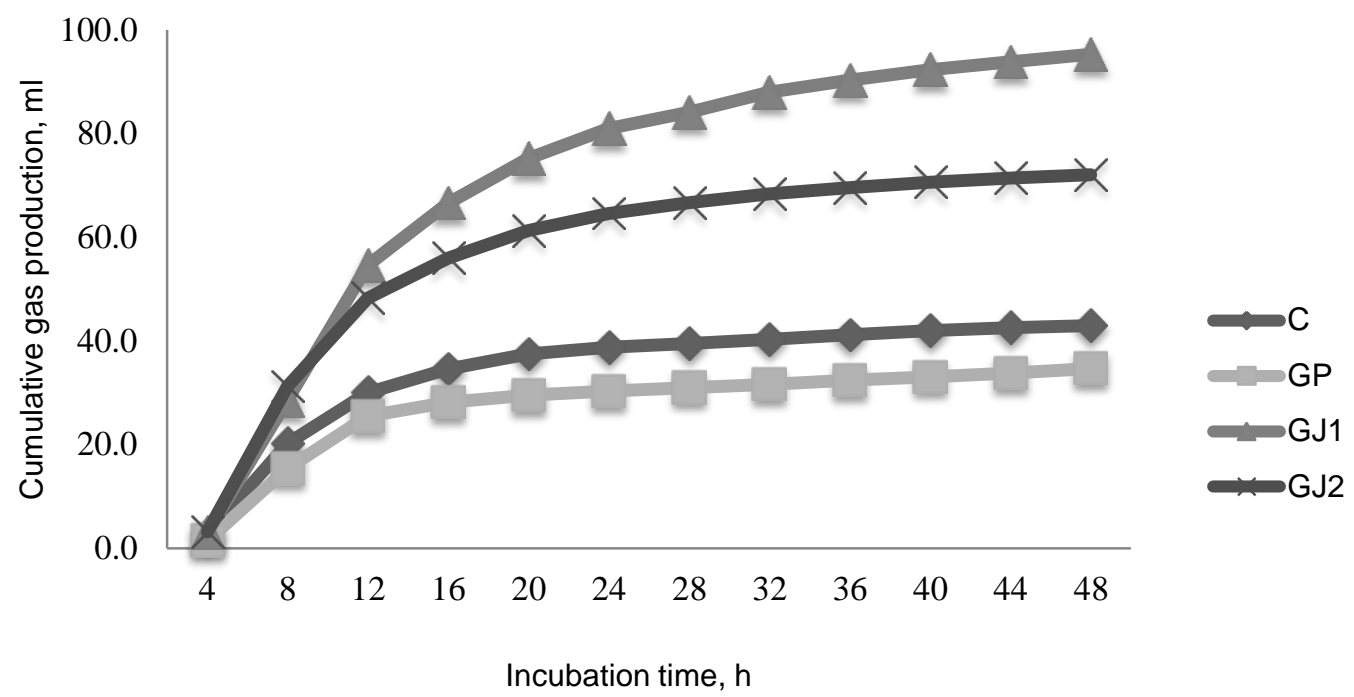

Figure 3 Cumulative gas production affected by garlic powder and garlic juice

C: control, GP: garlic powder, GJ: $0.5 \mathrm{ml}$ garlic juice, GJ2: 1,0 ml garlic juice

Natural plant extracts may be an alternative to ruminal modifiers. In the present study, the effects of garlic powder and garlic juice on DM digestibility resulted in significant differences among the garlic treatments, suggesting different activities of microbes and digestion. The current results for garlic powder were in accord with the findings of other reports that observed no changes in DM digestibility (Wanapat et al., 2008; Kongmun et al., 2010). Similar results were reported with garlic oil, diallyl disulfide and allyl mercaptan at various doses (Busquet et al., 2005b). Garlic juice supplemented at $1 \mathrm{~mL}$ reduced the digestion of DM compared with the control. Likewise, the effect of high level of garlic juice on DM digestibility agreed with in vivo findings of Ahmed et al. (2009), when garlic was supplied at $2.5 \%$ vs $7.5 \%$ in buffaloes. In their study, garlic juice supplemented at $7.5 \%$ reduced DM digestibility dramatically.

In the current study, supplementation of garlic powder and doses of garlic juice affected CP degradation differently. Compared with $\mathrm{C}$, all garlic supplements reduced the effective ruminal protein degradation. GJ1 reduced CP degradation more than GP and GJ2. Ferme et al. (2004) observed that garlic modified the microbial population profile by reducing the contribution of Prevotella species, which are responsible for protein degradation and $A A$ deamination in the rumen. In general, when proteins are protected from rumen deamination, ammonia decreases and ruminants may have more AA available for absorption. The effects observed in the present study confirm the mechanism whereby garlic interacts with sulfhydryl groups of protein and their biological active components (Reuter et al., 1996). In contrast to the current study, other reports observed no effect of garlic on protein degradation (Cardozo et al., 2004; Busquet et al., 2005a, 2005b). The difference in responses on protein degradation in comparison with the present study may be attributed to the dose (that is, $300 \mathrm{mg} / \mathrm{l}$ as opposed to $530 \mathrm{mg} / \mathrm{l}$ ), the types of extract (oil as opposed to powder or juice), the types of diet (that is, TMR vs hay or concentrate vs forage). Additionally, the length of incubation might have played a major role. For example, the experimental periods from Busquet et al. (2005a) and Cardozo et al. (2004) were longer (9 and 10 days) compared with the present study with two days of incubation. Cardozo et al. (2004) suggested that the inconsistent results may be attributed to differences in the rate of protein degradation, the rate of peptide use by rumen microbes that depend on the availability of energy, and the rate of peptide N. Bach et al. (2005) explained that factors such as the type of protein, rumen dilution rate, $\mathrm{pH}$ and predominant species of rumen microbes affect the process of protein degradation. Hart et al. (2007) suggested that the main effects of plant extracts in the rumen are the reduction of protein and starch degradation and the inhibition of AA degradation owing to the selection of certain bacteria. These effects are favourable in adult ruminants because nutritionists focus on additives with the potential to reduce ruminal protein degradation by reducing proteolysis, peptidolysis or deamination, which increase propionate production and decrease acetate and methane production without reducing the total VFA production (Kamel et al., 2008). Compared with control, supplementation of garlic had no effect on NDF digestibility, suggesting no activities on fibre digestion.

In the present study, garlic supplementation increased total VFAs in comparison with C. Volatile fatty acids are the end products of rumen fermentation and represent the main supply of energy for ruminants, 
and their reduction would be nutritionally unfavourable. In agreement with the present study, Cardozo et al. (2005) reported increased total VFA by garlic supplementation. In contrast, a decrease or no effect from garlic on the total VFA concentration was reported (Cardozo et al., 2004; Yang et al., 2007; Wanapat et al., 2008; Kongmun et al., 2010; Kongmun et al., 2011). The antimicrobial activity of garlic has been attributed to its sulphur compounds, particularly allicin (Ankri \& Mirelman, 1999) and increase with an additional S atom (Reuter et al., 1996; Ross et al., 2001). Garlic juice contains allicin (Kasuga et al., 2001), which might have contributed to the effect in the present study because of the short experimental period. This explains why garlic juice, which contains allicin (two $S$ atoms) resulted in a stronger effect than that of GP, which contains alliin (one $\mathrm{S}$ atom). None of the garlic extracts at these doses affected the molar proportion of acetate. In the present study, only garlic juice increased the molar proportion of propionate compared with $\mathrm{C}$. The addition of GP did not affect the molar proportion of propionate compared with $\mathrm{C}$. The increase in propionate proportions with garlic juice concurs with several in vitro studies (Busquet et al., 2005a, 2005b; 2006; Kongmun et al., 2010) that indicated consistently that garlic increased the proportion of propionate. In contrast, other studies reported no effects or decreased effects in the molar proportion of propionate (Wanapat et al., 2008; Anassori et al., 2012).

In concurrence with the present study, Anassori et al. (2012) observed a decrease in butyrate with raw garlic and an increase with garlic oil. Raw garlic contains the same ingredients found in GP (lberl et al., 1990), but differs in amounts of the active ingredients owing to the loss of volatile compounds during dehydration of garlic powder (Amagase et al., 2001). Other studies observed an increase in butyrate concentrations with supplemented garlic oil and suggested a consistency with fermentation profiles of methane inhibitors (Martin \& Macy, 1985). Busquet et al. (2005b) observed no effect of garlic oil and its compounds on the molar proportion of iso-butyrate and increased valerate proportion. Branched volatile fatty acids are derived from AA catabolism in the rumen (Mackie \& White, 1990). The ratio of C2 to C3 was significantly lowest when it was supplemented with GJ1 and GJ2, but increased in GP. Similar effects were observed in other studies (Busquet et al., 2006; Wanapat et al., 2008). The mechanism by which garlic extracts exert their antimicrobial effect on the molar proportion of VFA is not generally understood. GJ1 and GP reduced the NH3-N concentration, whereas high doses increased NH3-N concentration, suggesting that GP and GJ1 inhibited AA deaminase activity. The inhibition of AA deamination has an impact on in vivo because it may increase the ruminal escape of dietary protein and improve the efficiency of $\mathrm{N}$ use in the rumen (Van Nevel \& Demeyer, 1988). In contrast, in vivo studies reported no effect on ruminal NH3-N when garlic was fed to dairy cattle, which might be explained by the need for an adaptation period by microbes in long-duration experiments and allow the replacement of the inhibited microbial population by other resistant bacterial groups (Yang et al., 2007; Wanapat et al., 2008). However, the concentration of NH3-N in the rumen may increase (Hristov et al., 1999) or decrease (Devant et al., 2000), depending on several factors, including the amount of degradable protein and the amount and type of dietary carbohydrates available for microbial use (Russell et al., 1983). GJs had the lowest C2 to C3 ratio compared with control and GP. As noted with yeast, this might be because of the limiting effect of GJ on hydrogen metabolism in the rumen (Polyorach et al., 2014). The presence of concentrate in the diet changes ruminal VFAs concentrations in such way that less $\mathrm{C} 2$ and more $\mathrm{C} 3$ are produced.

Cumulative gas production was reduced with garlic powder. These results suggested that garlic powder had a weaker inhibition effect on fermentation rate. They are consistent with those of Kongmun et al. (2010), who reported a decrease in cumulative gas production when garlic powder was supplemented. Similarly, Anassori et al. (2012) reported a decrease in gas production with raw garlic and garlic oil. This could be explained by the loss of the main active ingredient in garlic powder during dehydration (Amagase et al., 2001). A low level of garlic juice could modify ruminal fermentation and increase gas production. The increased gas production was supported by increased DM digestibility. This is in agreement with Cullen et al. (2005), who reported that a high level of garlic reduced DM digestibility. The amount of cumulative gas produced in the rumen depends on the quantity of the substrate fermented and the amount and molar proportions of the VFA produced (Davies et al., 2000). In the present results, GJ1 and GJ2 increased total VFAs, which confirms the high value for gas production.

\section{Conclusion}

Garlic extracts may be useful in improving the efficiency of nutrient utilization in ruminants. Garlic supplements reduced CP degradability and increased the total VFAs. These results suggest that the supplementation of GJ1 would be the best in improving propionate production and reduction of NH3-N, and acetate to propionate ratio. Further studies are required to evaluate the effect of garlic extracts on the number of beneficial microbes in the rumen and active compounds in the extracts and the effective doses in vivo. 


\section{Acknowledgements}

This study was completed at the Agricultural Research Council- Animal Production Institute (South Africa, Irene). The authors thank the dairy unit crew for their support to this study.

\section{Authors' Contributions}

MRK designed the study, conducted the experimental work, data management and drafted the manuscript. DL contributed on the design of the study and recommended drafting of the manuscript and correction of the drafted manuscript. CM provided the rumen fluid and chemical reagents and data analysis. All authors read and approved the manuscript.

\section{Conflict of Interest Declaration}

The authors declare that there is no conflict of interest.

\section{References}

Ahmed, A.A., Bassuony, N.I, Awad, E.S., Aiad, A.M. \& Mohamed, S.A., 2009. Adding natural juice of vegetables and fruitage to ruminants' diets (B) nutrients utilization, microbial safety and immunity, effect of diets supplemented with lemon, onion and garlic juice fed to growing buffalo calves. World J. Agric. Sci. 5(4), 456-465.

Amagase, H., 2006. Clarifying the real bioactive constituents of garlic. J. Nutr. 136, 716s-725s. DOI: 10.1093/jn/136.3.716S

Amagase, H., Petesch, B.L., Matsuura, H., Kasuga, S. \& Itakura, Y., 2001. Intake of garlic and its bioactive components. J. Nutr. 131, 955s-962s. DOI: 10.1093/jn/131.3.955S

Anassori, E., Dalir-Naghadeh. B., Pirmohammadi, R., Taghizadeh, A., Asri-Rezaei, S., Farahmand-Azar, S., Besharati, M. \& Tahmoozi, M., 2012. In vitro assessment of the digestibility of forage based sheep diet, supplemented with raw garlic, garlic oil and monensin. Vet. Res. Forum 3(1), 5-11.

Ankri, S. \& Mirelman, D., 1999. Review: Antimicrobial properties of allicin from garlic. Microbes. Infect. 2, 125-129. DOI: 10.1016/S1286-4579(99)80003-3

AOAC, 2000. Official methods of analysis. Association of Official Analytical Chemists International. Maryland, USA.

Bach, A., Calsamiglia, S. \& Stern, M., 2005. Nitrogen metabolism in the rumen. J. Dairy Sci. 88, E9-E21. DOI: 10.3168/jds.S0022-0302(05)73133-7

Benchaar, C., Calsamiglia, S., Chaves, A.V., Fraser, G.R., Colombatto, D., Mcallister, T.A. \& Beauchemin, K.A., 2008. A review of plant-derived essential oils in ruminant nutrition and production. Anim. Feed. Sci. Tech. 145, $209-228$. DOI: 10.1016/j.anifeedsci.2007.04.014

Broderick, G.A., 2004. Effect of low level monensin supplementation on the production of dairy cows fed alfalfa silage. J. Dairy Sci. 87:359-368. DOI: 10.3168/jds.S0022-0302(04)73175-6

Busquet, M., Calsamiglia, S., Ferret, A. \& Kamel, C., 2006. Plant extracts affect in vitro rumen microbial fermentation. J. Dairy Sci. 89, 761-771. DOI: 10.3168/jds.S0022-0302(06)72137-3

Busquet, M., Calsamiglia, S., Ferret, A., Cardozo, P.W. \& Kamel, C., 2005a. Effects of cinnamaldehyde and garlic oil on rumen microbial fermentation in a dual flow continuous culture. J. Dairy Sci. 88, 2508-2516. DOI: 10.3168/jds.S0022-0302(05)72928-3

Busquet, M., Calsamiglia, S., Ferret, A., Carro, M.D. \& Kamel, C., 2005b. Effect of garlic oil and four of its compounds on microbial fermentation. J. Dairy Sci. 88(12), 4393-4404. DOI: 10.3168/jds.S0022-0302(05)73126-X

Cardozo, P.W., Calsamiglia, S., Ferret, A. \& Kamel, C., 2004. Effects of natural plant extracts on ruminal protein degradation and fermentation profiles in continuous culture. J. Anim. Sci. 82, 3230-3236. DOI: $10.2527 / 2004.82113230 x$

Cardozo, P.W., Calsamiglia, S., Ferret, A. \& Kamel, C., 2005. Screening for the effects of natural plant extracts at different $\mathrm{pH}$ on in vitro rumen microbial fermentation of a high-concentrate diet for beef cattle. J. Anim. Sci. 83, 2572-2579. DOI: 10.2527/2005.83112572x

Cullen, S.P., Monahan, F.J. \& Callan, J.J., 2005.The effect of dietary garlic and rosemary on grower-finisher pig performance and sensory characteristics of pork. Irish. J. Agr. Food. Res. 44, 57-67.

Davies, Z.S., Mason, D., Brooks, A.E., Griffith, G.W., Merry, R.J. \& Theodorou, M.K., 2000. An automated system for measuring gas production from forage inoculated with rumen fluid and its use in determining the effect of enzymes on grass silage. Anim. Feed. Sci. Tech. 83, 205-221. DOI: 10.1016/S0377-8401 (99)00138-8

Devant, M., Ferret, A., Gasa, J., Calsamiglia, S. \& Casals, R., 2000. Effects of protein concentration and degradability on performance, ruminal fermentation and nitrogen metabolism in rapidly growing heifers fed high-concentrate diets from 100 to $230 \mathrm{~kg}$ body weight. J. Anim. Sci. 78, 1667-1676. https://doi.org/10.2527/2000.7861667x

Ferme, D., Banjac, M., Calsamiglia, S., Busquet, M., Kamel, C. \& Avgustin, G., 2004. The effects of plant extracts on microbial community structure in a rumen-stimulating continuous-culture system as revealed molecular profiling. Folia. Microbio. 49, 151-155. DOI: 10.1007/bf02931391

Goering, H.K. \& Van Soest, P.J., 1970. Forage fibre analysis (apparatus, reagents, procedures and some applications). Agricultural handbook ARS-USDA, No. 379,1-20. USDA, Washington DC.

Hart, K.J., Yanez-Ruiz, D.R., Duval, S.M., McEwan, N.R. \& Newbold C.J., 2007. Plant extracts to manipulate rumen fermentation. Anim. Feed. Sci. Tech. 147, 1-28. https://doi.org/10.1016/j.anifeedsci.2007.09.007

Hristov, A.N., McAllister, T.A., Van Herk, F.H., Cheng, K.-J., Newbold, C.J. \& Cheeke, P.R., 1999. Effect of Yucca schidigera on ruminal fermentation and nutrient digestion in heifers. J. Anim. Sci. 77, 2554-2563. DOI: $10.2527 / 1999.7792554 x$ 
Iberl, B., Winkler, G., Muller, B. \& Knobloch, K., 1990. Quantitative determination of allicin and alliin from garlic by HPLC. Planta Medica 56, 320-326.

Kamel, C., Greathead, H.M.R., Tejido, M.J. \& Carro, M.D., 2008. Effects of allicin and diallyl disulphide on in vitro rumen fermentation on mixed diet. Anim. Feed Sci. Tech. 145, 351-363. https://doi.org/10.1016/j.anifeedsci.2007.05.050

Kasuga, S., Uda, N., Ushijima M, Morihara, N. \& Itakura, Y., 2001. Pharmacologic activities of aged garlic extract in comparison with other garlic preparations. J. Nutr. 131,1080s-1084s. https://doi.org/10.1093/jn/131.3.1080S

Klevenhusen, F., Zeitz, J.O., Duval, S., Kreuzer, M. \& Soliva, C.R., 2011. Garlic oil and its principal component diallyl disulphide fail to mitigate methane, but improve digestibility in sheep. Anim. Feed Sci. Tech. 166, 356-363. https://doi.org/10.1016/j.anifeedsci.2011.04.071

Kongmun, P., Wanapat, M., Pakde, P. \& Navanukraw, C., 2010. Effect of coconut oil and garlic powder on in vitro fermentation using gas production technique. Livest. Sci. 127, 38-44. https://doi.org/10.1016/j.livsci.2009.08.008

Kongmun, P., Wanapat, M., Pakdee, P., Navanukraw, C. \& Yu, Z., 2011. Manipulation of rumen fermentation and ecology of swamp buffalo by coconut oil and garlic powder supplementation. Livest. Sci. 135, 84-92.

Mackie, R.I. \& White, B.A., 1990. Recent advances in rumen microbial ecology and metabolism: Potential impact on nutrient output. J. Dairy Sci. 73, 2971-2995. DOI: 10.3168/jds.S0022-0302(90)78986-2

Marshall, B.M. \& Levy, S.B., 2011. Food animals and antimicrobials: Impacts on human health. Clin. Microbiol. Rev. 24, 718-733. DOI: 10.1128/CMR.00002-11

Martin, S.A. \& Macy, J.M., 1985. Effects of monensin, pyromellitic dimide and 2-bromoethanosulfonic acid on rumen fermentation in vitro. J. Anim. Sci. 60, 544-550. DOI: 10.2527/jas1985.602544x

Mauricio, R.M., Mould, F.L., Dhanoa, M.S., Owen, E., Channa, K.S. \& Heodorou, M.K., 1999. A semi-automated in vitro gas production technique for ruminant feedstuff evaluation. Anim. Feed. Sci. Tech. 79, 321-330. https://doi.org/10.1016/S0377-8401(99)00033-4

McGuffey, R.K, Richardson, L.F. \& Wilkinson, J.I.D., 2001. Ionophores for dairy cattle. Current status and future outlook. J. Dairy Sci. 84,194-203. DOI: 10.3168/jds.S0022-0302 (01)70218-4

National Research Council, 2001. Nutrient requirement of dairy cattle. 7th revised edition. National Academy of Science, Washington DC.

Odongo, N.E., Bagg, R., Vessie, G., Dick, P., Or-Rashid, M.M., Hook, S.E., Gray, J.T., Kebreab, E., France, J. \& McBride, B.M. 2007. Long-term effects of feeding monensin on methane production in lactating dairy cows. J. Dairy. Sci. 90,1781-1788. DOI: 10.3168/jds.2006-708

Polyorach, S., Wanapat, M. \& Cherdthong, A., 2014. Influence of yeast fermented cassava chip protein (YEFECAP) and roughage to concentrate ratio on ruminal fermentation and microorganisms using in vitro gas production technique. Asian. Austral. J. Anim. 27, 36-45. DOI: 10.5713/ajas.2013.13298

Reuter, H.D., Koch, J.P. \& Lawson, L., 1996. Therapeutic effects and applications of garlic and its preparations. In: H.P. Koch \& L.D. Lawson (eds). Garlic: The science and therapeutic application of Allium sativum L. and Related Species. Williams \& Wilkins, Baltimore, MD. Pp. 135-212.

Revlin, R.S., 2001. Historical perspective on the use of garlic. J. Nutr. 131, 951s-954s. DOI: 10.1093/jn/131.3.951S

Ross, Z.M., O'gara, E.A., Hill, D.J, Sleightholme, H.V. \& Maslin, D.J., 2001. Antimicrobial properties of garlic oil against human enteric bacteria: evaluation of methodologies and comparisons with garlic oil sulphides and garlic powder. Appl. Environ. Microbiol. 67,475-480. DOI: 10.1128/AEM.67.1.475-480.2001

Russell, J.B., Sniffen, C.J. \& Van Soest, P.J., 1983. Effect of carbohydrate limitation on degradation and utilization of casein by mixed rumen bacteria. J. Dairy Sci. 66, 763-775. https://doi.org/10.3168/jds.S0022-0302(83)81856-6

Theodorou, M.K., Williams, B.A., Dhanoa, M.S., Mcallan, A.B. \& France, J., 1994. A simple gas production method using a pressure transducer to determine the fermentation kinetics of ruminants fed. Anim. Feed. Sci. and Tech. 48, 185-197. https://doi.org/10.1016/0377-8401(94)90171-6

Van Nevel, C.J. \& Demeyer, D.I., 1988. Manipulation of rumen fermentation. In: P.N. Hobson (Ed.). The rumen microbial ecosystem. Elsevier Applied Science, London, UK. Pp. 387-443.

Van Soest, P.J. \& Robertson, J.B., 1985. Analysis of forage and fibrous foods. A laboratory manual for animal science 613. Cornell University, Ithaca, New York.

Wanapat, M., Khejornsart, P., Pakdee, P. \& Wanapat, S., 2008. Effect of supplementation of garlic powder on rumen ecology and digestibility of nutrient in ruminants. J. Sci. Food Agric. 88, 2231-2237. https://doi.org/10.1002/jsfa.3333

Windisch, W., Rohrer, E. \& Schedle, K., 2009. Phytogenic feed additives to young piglets and poultry: Mechanisms and application. In: T. Steiner (ed.). Phytogenics in animal nutrition: Natural concepts to optimize gut health and performance. Nottingham University Press, Nottingham, UK. Pp. 19-38. DOI: 10.2527/jas.2007-0459

Yang, W.Z., Benchaar, C., Ametaj, B.N., Chaves, A.V., He, M.L. \& McAllister, T.A., 2007. Effects of garlic and juniper berry essential oils on ruminal fermentation and on the site and extent of digestion in lactating cows. J. Dairy Sci. 90, 5671-5681. DOI: 10.3168/jds.2007-0369

Yang, S. \& Carlson, K., 2004. Routine monitoring of antibiotics in water and wastewater with a radioimmunoassay technique. Water Res. 38:3155-3166. DOI: 10.1016/j.watres.2004.04.028 